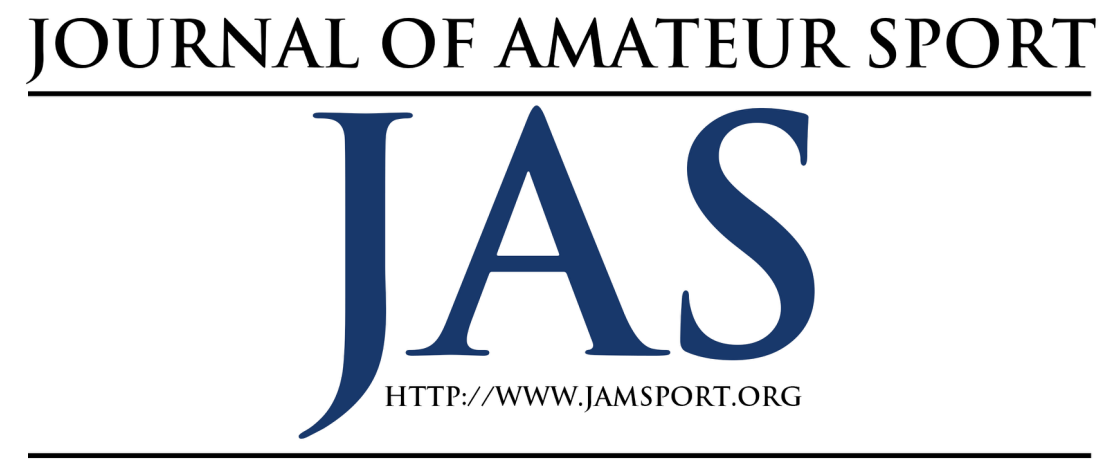

\title{
Concussion Knowledge of Youth Sport Athletes, Coaches, and Parents: A Review
}

\author{
Sungwon $\operatorname{Kim}^{1}$ \\ Robert F. Leeman ${ }^{1}$ \\ ${ }^{1}$ University of Florida
${ }^{2}$ University of New Mexico
}

Daniel P. Connaughton
Jong Hoon Lee

Mild traumatic brain injury, commonly known as a concussion, has gained widespread public attention. Approximately 1.1 to 1.9 million children 18 years old or younger suffer sport/recreation-related concussions in the U.S. annually. The purpose of this review was to assess research articles examining concussion knowledge of youth sport athletes, coaches and parents. Twenty-one articles published from 2009-2016 were selected. The results of this review suggest that most athletes, coaches, and parents had good knowledge regarding the definition of a concussion, common signs/symptoms, and complications from repeated concussions, while most stakeholders had moderate knowledge about the causes, prevalence, and return-to-play guidelines. However, the majority of respondents did not correctly identify the emotional signs/symptoms associated with concussions and did not know that youth concussions should be managed more conservatively than adult concussions. Notable knowledge deficiencies were found among youth athletes and parents. Suggestions to improve youth sport stakeholders' concussion knowledge are provided in the discussion.

S

port-related mild traumatic brain injury (m'TBI), known as a concussion, is a major public health issue among young athletes. Approximately 1.1 to 1.9 million children 18 years old or younger suffer sport or recreation-related concussions each year in the U.S. (Bryan, Rowhani Rahbar, Comstrock, \& Rivara, 2016). A concussion is a complicated brain injury that may cause cognitive, behavioral and physical impairments (Jotwani \& Harmon, 2010). Typical signs and 
symptoms of a concussion include, but are not limited to, headache, nausea, dizziness, vertigo, difficulty concentrating, drowsiness, slow reaction time, difficulty sleeping, emotional changes, anxiety, and sadness (Halstead \& Walter, 2010; McCrory et al., 2017; Meehan \& Bachur, 2009). Athletes who sustain another concussion without completely recovering from the previous one can suffer a rare condition known as second impact syndrome which may cause brain swelling, herniation, and even death (Buzzini \& Guskiewicz, 2006; McCrory, Davis, \& Makdissi, 2012). Additionally, athletes who sustain repetitive concussions may also suffer long-term health problems such as cognitive impairment and depression (National Research Council \& Committee on Sports-Related Concussions in Youth, 2014). Athletes with a concussion, therefore, should be seen by an appropriate healthcare provider and follow individualized return-to-play (RTP) guidelines to avoid potential catastrophic health consequences (Harmon et al., 2013).

At the youth sport level, where healthcare providers (i.e., athletic trainers, team physicians) are not typically available onsite, the recognition, management (i.e., following healthcare provider(s) advice, and RTP guidelines), and the prevention of youth concussions is particularly important for youth sport stakeholders (YSS). For the purpose of this review, YSS were defined as athletes, coaches, and parents, and did not include clinicians (e.g., physicians, athletic trainers, school nurses, physical therapists).
Compared to adults, youth sport athletes are at greater risk of sustaining concussions due to their premature brain structures and physiological weaknesses (Karlin, 2011). Additionally, younger athletes with a concussion typically require longer recovery time than adults (Covassin, Elbin, \& Sarmiento, 2012). Accordingly, proper care and diligence must be provided to younger athletes particularly when deciding when to return to play.

Efforts to recognize, manage, and prevent concussions at the youth sport level have been primarily accomplished by providing concussion education to YSS. Consensus-based concussion education focuses on the proper identification of signs/symptoms, assessment, treatment, and RTP guidelines (Harmon et al., 2013). The need for concussion education stems from the fact that concussions are often difficult to diagnose and frequently go unrecognized which may result in underreporting, particularly among athletes. Several research studies found that more than $50 \%$ of concussive incidences were unreported due to athletes' lack of understanding the signs/symptoms and not thinking that the injury may have been a concussion (Delaney, Lacroix, Leclerc, \& Johnson, 2002; Echlin et al., 2010; McCrea, Hammeke, Olsen, Leo, \& Guskiewicz, 2004; Register-Mihalik, Linnan, Marshall, Valovich McLeod, Mueller, \& Guskiewicz, 2013). Although it is premature to suggest that increased concussion knowledge may help reduce concussions, one study reported 
that concussion knowledge was an important predictor of recognizing and reporting symptoms to appropriate medical personnel (Sefton, Pirog, Capitao, Harackiewicz, \& Cordova, 2004). Additionally, although most concussions have been found to occur during games (Daneshvar, Nowinski, McKee, \& Cantu, 2011; Gessel, Fields, Collins, Dick, \& Comstock, 2007; Marar, McIlvain, Fields, \& Comstock, 2012), it has been reported that athletes' increased knowledge was associated with increased reporting of concussions during practices (RegisterMihalik et al., 2013).

Over the past few years, a number of organizations (e.g., CDC, National Federation of State High School Associations) have made concussion education resources available and/or provided safety recommendations for YSS. Additionally, national youth sport organizations (e.g., Pop Warner, Little League Baseball, US Youth Soccer) have established concussion safety policies that require and/or recommend YSS review concussion educational resources as a prerequisite for participation (Paradis, 2014; Sussingham, 2015). The requirement of educating YSS about concussion safety has also stemmed from legislative mandates (i.e., youth sport concussion statutes) in all 50 states and the District of Columbia (Lowrey, 2014).

To the best our knowledge, there is a relatively small number of studies that examined baseline concussion knowledge of
YSS prior to the implementation of state concussion legislation (Washington was first to do so in 2009), and such findings suggested a mixed level of knowledge (Guilmette, Malia, \& McQuiggan, 2007; Valovich McLeod, Schwartz, \& Bay, 2007). Presumably due to heightened public awareness stemming from concussion legislation, related lawsuits, and media attention, since 2009, a significant number of studies have assessed YSS's concussion knowledge. The purpose of this review was to evaluate YSS's baseline knowledge (i.e., recognition, management and prevention) regarding youth concussions. No comprehensive review of YSS's baseline concussion knowledge has been conducted to date. The specific research questions guiding this review were: What knowledge items (e.g., signs and symptoms, RTP guidelines, etc.) were commonly assessed? What types of instruments were used to examine concussion knowledge? What are the stakeholders' strengths and weaknesses regarding concussion knowledge? Is there any particular stakeholder(s) that demonstrates a deficit(s) in concussion knowledge? The results of this review may be used to inform policy makers and sport governing bodies to develop, revise, and/or promote effective concussion educational programs and safety policies/practices at the youth sport level.

\section{Method}

The present review examined research articles published during 2009-2016 (i.e., 8- 
year-span) to assess the overall level of YSS's concussion knowledge. We selected this 8-year time frame because the first youth sport-related concussion statute in the U.S. was implemented in 2009 and likely created a heightened awareness regarding youth sport-related concussions. Additionally, we found a notably large number of relevant published articles during this period.

A total of 872 articles were identified using the PubMed and SPORTDiscus databases before being screened for eligibility. Keywords utilized for the primary search included concussions ("concussions", OR "brain injury", OR "sport concussions" OR "mild traumatic brain injury" OR "mTBI"), AND knowledge ("knowledge", OR "baseline knowledge"), management ("management", OR “awareness", OR "familiarity", OR "recognition", OR "evaluation", OR "prevention," OR "understanding") AND youth sport stakeholders ("athletes", OR "coaches", OR "parents"). During the search, we used the keywords independently and in multiple combinations. We also reviewed references found in the initially retrieved articles and then finally conducted additional searches (i.e., utilizing Google Scholar, Internet search). The specific inclusion and exclusion criteria for selecting articles for this review were:

1. Youth sport refers to both interscholastic and recreational sport programs where the majority of the participants are 18 years of age or under.

2. Studies must have examined baseline concussion knowledge. For intervention studies (including those that utilized control conditions), only assessment of baseline concussion knowledge was reported if available.

3. Studies evaluating health care providers/clinicians (e.g., athletic trainers, nurses, physical therapists, physicians) were excluded from this review. The purpose of this review was to assess studies examining concussion knowledge of non-clinical YSS (i.e., youth sport athletes, coaches and parents).

4. Studies conducted outside of the U.S. or Canada were not included since public perception and awareness toward sport-related concussion may be significantly different than those found in these two countries.

5. Studies that did not examine objective knowledge measures (i.e., those measuring perception, attitude, opinions, agreements, practices, policies, etc.) were excluded.

6. Studies must have been published in a peer-reviewed journal.

7. Studies must have been original research (i.e., no review studies or book chapters).

8. Studies must have been written in English.

After utilizing the aforementioned keywords and inclusion/exclusion criteria, 
study titles and abstracts were reviewed for relevance to the present review. For selection purposes, relevant articles were then further screened through a full-text review (see Figure 1).

\section{Results}

After the screening process, a total of 21 articles published from 2009 through 2016 were selected for review. Questions regarding a study's inclusion/exclusion were resolved through a discussion among the current investigators. All 21 articles utilized a survey instrument to gauge respondents' concussion knowledge. The questionnaires included a combination of true/false, Likert scale, closed-ended, open-ended and multiple-choice questions. However, none of the reviewed studies utilized a standardized survey instrument and most of the studies did not indicate whether the questionnaire had been validated. All studies included in this review developed a unique questionnaire based upon the literature, consensus statements, position statements, educational resources (e.g., CDC's Heads Up materials), Sport Concussion Assessment Tool (SCAT), and/or expert opinions. Five studies adopted and/or slightly modified a previously utilized survey (Anderson, Gittelman, Mann, Cyriac, \& Pomerantz, 2016; Gourley, Valovich McLeod, \& Bay, 2010; Kurowski, Pomerantz, Schaiper, \& Gittelman, 2014; Kurowski, Pomerantz, Schaiper, Ho, \& Gittelman 2015; Shroyer \& Stewart, 2016).
Reviewed studies assessed concussion knowledge from athletes $(k=9)$, coaches $(k$ $=9)$, and parents $(k=8)$. It should be noted that some articles surveyed more than one stakeholder (Bloodgood et al., 2013; Cusimano, 2009; Gourley et al., 2010; Shenouda, Hendrickson, Davenport, Barber, \& Bell, 2012). Overall, YSS included in this review were associated with interscholastic and/or recreational youth sport programs where the majority of the participants were 18 years of age or under. Twelve studies examined interscholastic sport stakeholders and nine studies examined recreational YSS's concussion knowledge. The vast majority of reviewed studies involved a contact and/or collision sport (e.g., football, soccer, hockey, wrestling, lacrosse, etc.) which are known for higher incidences of concussions. Among the studies reviewed, the knowledge items assessed varied widely due to a lack of uniformity in the surveys utilized. However, the most popular knowledge items were (1) key facts about concussions, such as definition, causes, prevalence, and youth concussion care; (2) signs/symptoms; (3) RTP guidelines; and (4) medical complications from repeated concussions. We chose these four categories as key knowledge measures since they reflect best practices based on consensus (McCrory et al., 2017) and position statements (Broglio et al., 2014). A summary of the articles reviewed can be found in Table 1 . The remainder of this section will provide a synthesis of each stakeholder's knowledge 
from the four selected knowledge assessment categories.

\section{Youth Concussion Facts}

Sixteen studies examined key concussion facts. These included but were not limited to definition, causes, prevalence, and management of youth concussions. The vast majority ( $\geq 80 \%$ ) of athletes (Cusimano, 2009; Mrazik, Perra, Brooks, \& Naidu, 2015; Register-Mihalik et al., 2013), parents (Cusimano, 2009; Shenouda et al., 2012) and coaches (Cusimano, 2009; Mrazik, Bawani, \& Krol, 2011; Shenouda et al., 2012; Shroyer \& Stewart, 2016) understood that a concussion is a form of mTBI. However, in one study, only $34.7 \%$ of parents identified the correct definition of a concussion (Mannings, Kalynych, Joseph, Smotherman, \& Kraemer, 2014).

In regard to the causes of concussions, studies reviewed indicated mixed results. Promisingly, most $(\geq 80 \%)$ athletes (Mrazik et al., 2015), coaches (Chrisman, Schiff, Chung, Herring, \& Rivara, 2014; Mrazik et al., 2011; Shroyer \& Stewart, 2016), and parents (Coghlin, Myles, \& Howitt, 2009) knew that a concussion could be caused by a blow to the body (e.g., neck, jaw) other than the head. Meanwhile, four studies reviewed suggested knowledge deficiencies in athletes and parents regarding the causes of concussions. For instance, Bloodgood et al. (2013) revealed that only a quarter of both athletes and parents knew a concussion can be caused by a blow other than to the head. Similarly, other studies suggested knowledge deficits (i.e., only 58$61 \%$ of respondents answered correctly) in understanding the causes of concussions among parents (Mannings et al., 2014) and athletes (Kurowski et al., 2014; Kurowski et al., 2015).

The likelihood of suffering another concussion is greater if an athlete has not recovered from a previous one. Four studies (Anderson et al., 2016; Kurowski et al., 2014; Kurowski et al., 2015; Mrazik et al., 2011) that examined factors associated with repetitive concussions (i.e., prevalence) showed mixed results based on the type of stakeholder. Specifically, while the vast majority $(91.6 \%)$ of coaches agreed that the likelihood of another concussion increases with a previous history (Mrazik et al., 2011), a moderate (65-77\% correctly responded) level of knowledge regarding the likelihood of suffering another concussion was found among youth sport athletes (Anderson et al., 2016; Kurowski et al., 2014; Kurowski et al., 2015).

Finally, three studies (LaBond, Barber, \& Golden, 2014; O’Donoghue, Onate, Van Lunen, \& Peterson, 2009; Shroyer \& Stewart, 2016) examined whether YSS understood that youth concussions should be managed more conservatively than those sustained by older athletes due to their physiological differences. The results of these studies overall revealed a low-tomoderate level of knowledge regarding the importance of conservatively managing youth concussions. Specifically, $48 \%$ of coaches did not believe that youth athletes 
typically take longer than adults to recover from concussions (Shroyer \& Stewart, 2016), and approximately $57 \%$ of coaches believed that all athletes, regardless of age, recover at the same rate (O'Donoghue et al., 2009). Additionally, approximately $33 \%$ of parents disagreed or did not know that head trauma was typically more serious in younger athletes (LaBond et al., 2014).

\section{Signs and Symptoms}

Seventeen articles assessed YSS's understanding of concussion signs and symptoms. The overall results revealed that most athletes, coaches, and parents, in general, had good knowledge in recognizing the key indicators of a concussion. The majority of YSS in several studies correctly identified commonly perceived signs/symptoms. Specifically, over $80 \%$ of athletes (Anderson et al., 2016; Cournoyer \& Tripp, 2014; Kurowski et al., 2014; Kurowski et al., 2015; Register-Mihalik et al., 2013), coaches (Chrisman et al., 2014; Mrazik et al., 2011; Naftel, Yust, Nichols, King, \& Davis, 2014; O’Donoghue et al., 2009; Shenouda et al., 2012), and parents (Coghlin et al., 2009; Mannings et al., 2014; Shenouda et al., 2012) correctly identified headache, dizziness, confusion, memory loss, and blurred vision as common signs/symptoms of concussions. Furthermore, over $80 \%$ of athletes (Anderson et al., 2016; Cournoyer \& Tripp, 2014; Register-Mihalik et al., 2013) and coaches (Mrazik et al., 2011; Shroyer \& Stewart, 2016) were aware that a loss of consciousness is not necessary to sustain a concussion.

The overall findings from studies reviewed revealed a gap in YSS's knowledge in understanding the subtle deficits and/or less distinct signs/symptoms of a concussion. For instance, approximately $30-$ $70 \%$ of athletes (Cournoyer \& Tripp, 2014; Kurowski et al., 2014; Kurowski et al., 2015), coaches (Chrisman et al., 2014), and parents (Mannings et al., 2014) did not recognize emotional changes. Additionally, $30-60 \%$ of athletes (Cournoyer \& Tripp, 2014), coaches (Naftel et al., 2014), and parents (Coghlin et al., 2009; Mannings et al., 2014) did not know that sleep problems can be associated with concussions. Furthermore, approximately $40-70 \%$ of athletes (Cournoyer \& Tripp, 2014) and coaches (Chrisman et al., 2014) did not identify anxiety/nervousness, while approximately $40-50 \%$ of athletes (Cournoyer \& Tripp, 2014 Kurowski et al., 2014; Kurowski et al., 2015) did not identify vomiting, as potential signs/symptoms of a concussion.

\section{Return to Play (RTP) Guidelines}

RTP guidelines were another key knowledge item that many of the reviewed studies $(k=13)$ examined. Articles assessing respondents' familiarity with RTP guidelines, however, reported mixed results based on the type of stakeholders. Promisingly, most (80-100\%) coaches (Bramley, Kroft, Polk, Newberry, \& Silvis, 2012; Coghlin et al., 2009; Esquivel, Haque, 
Keating, Marsh, \& Lemos, 2013; Shroyer \& Stewart, 2016) recognized that same day return to play is not recommended once a concussion is suspected. Moreover, $88 \%$ of coaches (Shenouda et al., 2012; Shroyer \& Stewart, 2016) and parents (Shenouda et al., 2012) were aware that parents/guardians of an athlete should not provide clearance for a RTP decision. Furthermore, according to Chrisman et al. (2014), approximately 95\% of coaches indicated that they would not allow an athlete to return to play even if symptoms were present briefly (i.e., 15 minutes or less).

Meanwhile, respondents from six studies did not completely understand specific RTP components such as the importance of medical clearance before returning to play. For instance, only $63 \%$ of athletes (Kurowski et al., 2015) reported that they should be thoroughly evaluated by medical personnel after a concussion to make sure they are recovered, and only $73 \%$ of coaches and parents (Shenouda et al., 2012) knew that soccer players must receive written clearance from an appropriate healthcare provider to return to play. Additionally, only $55.2 \%$ of coaches were familiar with the concept of "graduated return to play" (Chrisman et al., 2014). Similarly, Gourley et al. (2010) found only $62 \%$ of athletes and $56 \%$ of parents both agreed that a young athlete should RTP in a slow progressive manner if symptom free (i.e., graduated return to play). Interestingly, in one study, while $99 \%$ of coaches would never allow an athlete to RTP with a severe concussion, approximately $16 \%$ would allow a player to RTP with a minor concussion (Bramley et al., 2012). Finally, 33-40\% of hockey players thought, as long as they were feeling better, they could return to play on the same day they sustained a concussion (Cusimano, 2009).

\section{Medical Complications}

Six studies examined whether YSS knew that repeated concussions and premature return to play can lead to catastrophic health consequences (i.e., second impact syndrome). Stakeholders from the majority of studies reviewed correctly indicated that athletes who sustain a second concussion (before fully recovering from a previous one) could suffer serious health consequences. For instance, $83-92 \%$ of athletes (Anderson et al., 2016; Kurowski et al., 2015), coaches (Shenouda et al., 2012), and parents (Shenouda et al., 2012) were aware of the risk of serious injury or death if a second concussion occurs before a previous one is fully healed. Also, over $85 \%$ of athletes correctly identified potential complications of a concussion which included brain damage and memory problems (Register-Mihalik et al., 2013). Cournoyer \& Tripp (2014), however, reported that only $60-70 \%$ of high school athletes correctly identified brain hemorrhage, coma, and death as potential consequences of a concussion.

Although evidence regarding the longterm effects of concussions is not conclusive, only a few athletes were able to 
identify early-onset Alzheimer's (47\%), dementia (64\%), and Parkinson's disease $(28 \%)$ as potential consequences from repetitive and/or improper management of concussions (Cournoyer \& Tripp, 2014). Similarly, according to LaBond et al. (2014), $35 \%$ of parents did not know that repeated head trauma could lead to dementia.

\section{Discussion}

Over the last decade, the topic of youth sport-related concussions has received considerable attention from the scientific community. Additionally, heightened public awareness likely stemming from concussion legislation, related lawsuits, and media attention has emphasized the need for concussion recognition, management, and prevention among YSS. The purpose of this review was to examine baseline concussion knowledge (i.e., recognition, management and prevention) of youth sport athletes, coaches, and parents. Given the complicated nature of properly recognizing and managing concussions, it is imperative that stakeholders are knowledgeable about, and undertake a concerted effort to reduce concussions. Based on the present review, YSS demonstrated good concussion knowledge overall while exhibiting deficiencies in some areas.

Improved stakeholder knowledge may be attributed to several recent educational initiatives aimed at increasing concussion awareness and knowledge particularly at the youth sport level. These resources (available online and at no-cost) include but are not limited to the CDC's Heads Up initiative (CDC, 2016), NFHS's Concussion in Sports (NFHS, 2017), and Brain 101: The Concussion Playbook (ORCAS, 2011). Several studies demonstrated the effectiveness of educational interventions (e.g., concussion videos, lectures, web-based resources, etc.) which helped increase concussion knowledge of athletes (Cusimano, Chipman, Donnelly, \& Hutchison, 2014; Glang et al., 2015; Miyashita, Timpson, Frye, \& Gloeckner, 2013), coaches (Covassin, et al., 2012), parents (Glang et al., 2015), and non-athlete students (Bagley et al., 2012; Falavigna et al., 2012).

Meanwhile, knowledge gaps among some stakeholders remain. A number of studies revealed that parents and athletes, in particular, did not have strong knowledge regarding key concussion facts, RTP guidelines and potential medical complications. Chrisman et al. (2014) noted that a lack of concussion knowledge among athletes and parents may be due to the vague language in state concussion statutes (i.e., concussion education requirement). In fact, not all concussion statutes specify the type of education required for parents and/or athletes (Harvey, 2013). While some statutes state an "information sheet" as a specific method of knowledge dissemination under the educational provision, several statutes do not specify a method for conveying such education. This vagueness may have created challenges in offering concussion education and 
subsequently failing to improve both athletes' and parents' knowledge. Future legislative efforts should consider clarifying the specific requirements regarding concussion education in state concussion statutes.

Furthermore, educational initiatives have not been as common for parents of youth sport athletes when compared to coaches (Sarmiento, Mitchko, Klein, \& Wong, 2010). Presumably due to a subsequent lack of knowledge, it is likely that some parents may not believe concussions warrant proper medical care and sufficient recovery time. Perhaps some parents perceive a concussion merely as a "bell ringer" or "ding" and, therefore, treat it as a mild injury. Indeed, many parents who participated in youth sports themselves may have been taught such. Given parents' close involvement with young athletes, it is important that they understand concussion signs/symptoms and the importance of seeking proper medical care. In 2013, the CDC launched a concussion toolkit (i.e., Heads Up to Parents) specifically designed for parents of youth sport athletes. Similar to their previous concussion educational initiatives (e.g., Heads Up to Youth Sports, Heads Up to School Sports), the parents' toolkit contains valuable concussion safety educational materials that are tailored to parents (CDC, 2016).

The results of this review are consistent with previous research (Delaney et al., 2002; McCrea et al., 2004), in which youth sport athletes generally had a poorer understanding of recognizing, managing and preventing concussions compared to other stakeholders (e.g., coaches, health care providers). Perhaps, younger athletes' concussion knowledge may have been negatively influenced by the culture in sports which often emphasizes "sacrifice" and "playing through pain" (Howe, 2004; Young \& White, 1995), which could impact an athlete's desire to learn and appreciate the value of concussion education. In McCrea et al. (2004), two-thirds of high school athletes did not report potential concussions because they did not want to be removed from a game. Likewise, Register-Mihalik et al. (2013) found that "letting down" teammates and coaches was a primary reason for not reporting suspected concussions. Furthermore, Kurowski et al. (2014) revealed that improved knowledge and previous education were not associated with selfreporting concussions. Such findings suggest that educational initiatives alone may influence young athletes' concussion safety behaviors (i.e., reporting symptoms to coaches and parents). Therefore, stakeholders, particularly those in leadership roles (e.g., coaches and administrators), should attempt to change the youth sport culture by fostering an environment where athletes are encouraged to take proper measures to identify and report concussions. Furthermore, young athletes may not take concussion education seriously because they may not perceive a concussion to be a serious injury and may also think 
they are less vulnerable to suffer a concussion compared to older athletes (Mrazik et al., 2015). Relevant to such beliefs, Elkind (1985) posited that younger children often believe the adverse effects of risky behaviors will not apply to them. Future efforts, therefore, should not only consider implementing effective educational programs, but also focus on increasing awareness and attitudinal changes among younger athletes.

Although concussion education should be directed to all relevant YSS, optimal knowledge transfer (KT) strategies have not been studied extensively (Provvidenza \& Johnson, 2009). The purpose of KT strategies is to bridge the knowledge gap between the scientific/medical community and the general public (e.g., youth sport coaches, athletes, and parents) that use such knowledge (Straus, Tetroe, \& Graham, 2013). In fact, KT strategies should consider the needs of the target audience, as well as the type, content, and quality of educational materials (Provvidenza et al., 2013). Passive concussion education (e.g., printed materials, handouts, and websites) may not lead to significant behavioral changes over time if such sources are used as a standalone method (Grimshaw et al., 2001). Instead, interactive $\mathrm{KT}$ strategies that deliver concussion education over multiple sessions should be utilized in an effort to have a long-term effect on the stakeholders' concussion knowledge, attitudes, and behaviors. Research (Ahmed, Sullivan, Schneiders, \& McCrory, 2010; Sullivan et al., 2012; Williams, et al., 2014) suggests using social media (i.e., Facebook, Twitter, YouTube) to deliver concussion education programs although its effectiveness needs to be studied further. Additionally, Provvidenza et al. (2013) suggests integrating several educational strategies including the use of video, case studies, social media, handouts, oral presentations and discussions that can be delivered over multiple sessions to better suit individuals with different learning styles. Future research should continue to evaluate optimal KT strategies for concussion education programs, particularly considering the knowledge to action cycle.

The present review is not without limitations. First, although all reviewed studies were published from 2009 through 2016, data collection procedures in some studies were conducted several years prior to the publication date. Such lag in time may not have accurately depicted the stakeholders' most recent concussion knowledge, particularly after the implementation of concussion legislation. However, to the best of our knowledge, all data in the reviewed studies were collected no more than four years prior to the publication date. Second, due to the use of convenience sampling (i.e., selection bias) in several reviewed studies, there was a wide variation in the stakeholder's demographics. Such variation is concerning because research suggests that age, education, gender, and socioeconomic status can affect the stakeholders' concussion knowledge 
(Bagley et al., 2012; Kurowski et al., 2014; Lin et al., 2015). The present review was, therefore, a holistic evaluation of YSS's concussion knowledge and may have unintentionally disregarded the aforementioned demographics which could have affected their baseline knowledge. Third, articles retrieved for consideration were obtained primarily from two databases (i.e., PubMed and SPORTDiscus). We also utilized references from the selected articles as well as from other sources (i.e., Google Scholar, Internet search) to retrieve additional articles for consideration. Therefore, we believe the present review, when conducted, represented the full body of literature (from 2009-2016) on baseline concussion knowledge of youth sport athletes, coaches, and parents.

Due to the frequency and potential severity of youth concussions, efforts from various stakeholders are necessary to reduce concussions in youth sport. To date, research has assessed concussion knowledge of stakeholders other than athletes, coaches, and parents. For instance, concussion knowledge of healthcare providers/clinicians (Zemek et al., 2014; Zemek et al., 2015), athletic trainers (Cusimano et al., 2009; Esquivel et al., 2013 Naftel et al., 2014), physical therapists (Yorke, Littleton, \& Alsalaheen, 2016), and speech-language pathologists (Duff \& Stuck, 2015), has been examined. Such stakeholders may play pivotal roles in reducing and managing youth concussions. Future research should consider evaluating the knowledge of these important stakeholders who are primarily responsible for the clinical management of concussions. Furthermore, future investigation on this topic should center on comparing YSS's concussion knowledge pre and post-state law implementation. Concussion legislation was passed in all states from 2009 to 2014 (Lowrey, 2014). Additionally, comparing concussion knowledge of recreational sport stakeholders versus interscholastic sport stakeholders is warranted since some state legislation only applies to interscholastic competitions.

Although several of the studies reviewed examined key knowledge items such as concussion facts, signs/symptoms, RTP guidelines and medical complications, future research should consider assessing other important knowledge constructs. Recently, concussion management strategies for student-athletes have been centered on "return-to-learn" or "academic accommodation" for those with previous concussions (Weber, Welch, Parsons, \& Valovich McLeod, 2015). Consensus guidelines strongly recommend that concussed student-athletes take cognitive rest before returning to full academic activities (McCrory et al., 2017). Cognitive rest allows the brain to recover and prevents exacerbation of existing concussive symptoms (Moser, Glatts, \& Schatz, 2012).

Finally, all of the studies reviewed utilized questionnaires which were developed after a review of the literature and/or by revising previously used surveys. 
To the best of our knowledge, at the time of this review, there was not a standardized questionnaire that measured baseline concussion knowledge. The Rosenbaum Concussion Knowledge and Attitudes Survey (RCKAS) is one of very few standardized instruments that assesses concussion knowledge and attitude of youth sport athletes (Rosenbaum \& Arnett, 2010); however, none of the studies reviewed utilized this instrument. Also, it is unknown whether several of the studies reviewed used validated questionnaires. Future research should focus on creating a standardized, psychometrically-valid instrument, which would allow for more effective knowledge comparisons across stakeholder groups and increase the rigor in evaluating baseline concussion knowledge.

\section{Conclusion}

Based on the present review, the overall findings suggest that although most YSS demonstrated good overall concussion knowledge, knowledge gaps in certain areas were found among athletes and parents in particular. A significant number of articles assessing athletes' and parents' concussion knowledge revealed that these groups had many misconceptions about key concussion facts, RTP guidelines, and medical complications. These groups, therefore, should be targeted for more extensive concussion education. Finally, it is suggested that youth sport organizations adopt widely accepted concussion safety policies/practices (i.e., CDC, 2016; NFHS, 


\section{References}

Ahmed, O. H., Sullivan, S. J., Schneiders, A. G., \& McCrory, P. (2010). iSupport: Do social networking sites have a role to play in concussion awareness? Disability and Rehabilitation, 32(22), 1877-1883.

Anderson, B. L., Gittelman, M. A., Mann, J. K., Cyriac, R. L., \& Pomerantz, W. J. (2016). High school football players' knowledge and attitudes about concussions. Clinical Journal of Sport Medicine, 26(3), 206-209.

Bagley, A. F., Daneshvar, D. H., Schanker, B. D., Zurakowski, D., D'hemecourt, C. A., Nowinski, C. J.,... Goulet, K. (2012). Effectiveness of the SLICE program for youth concussion education. Clinical Journal of Sport Medicine, 22(5), 385-389.

Bloodgood, B., Inokuchi, D., Shawver, W., Olson K, Hoffman R, Cohen E.,... Muthuswamy, K. (2013). Exploration of awareness, knowledge, and perceptions of traumatic brain injury among American youth athletes and their parents. Journal of Adolescent Health, 53(1), 34-39.

Bramley, H., Kroft, C., Polk, D., Newberry, T., \& Silvis, M. (2012). Do youth hockey coaches allow players with a known concussion to participate in a game? Clinical Pediatrics, 51(3), 283287.

Broglio, S. P., Cantu, R. C., Gioia, G. A., Guskiewicz, K. M., Kutcher, J., Palm, M., \& Valovich Mcleod, T. C. (2014).
National Athletic Trainers'

Association position statement:

Management of sport concussion.

Journal of Athletic Training, 49(2), 245265.

Bryan, M. A., Rowhani-Rahbar, A., Comstock, R. D., \& Rivara, F. (2016). Sports and recreation-related concussions in US youth. Pediatrics, 138(1), e20154635.

Buzzini, S. R. R., \& Guskiewicz, K. M. (2006). Sport-related concussion in the young athlete. Current Opinion in Pediatrics, 18(4), 376-382.

Centers for Disease and Control and Prevention. (2016). Heads up: Concussion in youth sports. Retrieved fromhttp://www.cdc.gov/concussio $\mathrm{n} /$ Headsup/training/

Chrisman, S. P., Schiff, M. A., Chung, S. K., Herring, S. A., \& Rivara, F. P. (2014). Implementation of concussion legislation and extent of concussion education for athletes, parents, and coaches in Washington State. American Journal of Sports Medicine, 42(5), 1190-1196.

Coghlin, C. J., Myles, B. D., \& Howitt, S. D. (2009). The ability of parents to accurately report concussion occurrence in their bantam-aged minor hockey league children. Journal of the Canadian Chiropratic Association, 53(4), 233-250.

Cournoyer, J., \& Tripp, B. L. (2014).

Concussion knowledge in high 
school football players. Journal of Atbletic Training, 49(5), 654-658.

Covassin, T., Elbin, R. J., \& Sarmiento, K. (2012). Educating coaches about concussion in sports: Evaluation of the CDC's "Heads Up: Concussion in Youth Sports" initiative. Journal of School Health, 82(5), 233-238.

Cusimano, M. D. (2009). Canadian minor hockey participants' knowledge about concussion. Canadian Journal of Neurological Sciences, 36(3), 315-320.

Cusimano, M. D., Chipman, M., Donnelly, P., \& Hutchison, M. G. (2014). Effectiveness of an educational video on concussion knowledge in minor league hockey players: A cluster randomised controlled trial. British Journal of Sports Medicine, 48(2), 141146.

Daneshvar, D. H., Nowinski, C. J., McKee, A. C., \& Cantu, R. C. (2011). The epidemiology of sport-related concussion. Clinics in Sports Medicine, 30(1), 1-17.

Delaney, J. S., Lacroix, V. J., Leclerc, S., \& Johnston, K. M. (2002). Concussions among university football and soccer players. Clinical Journal of Sport Medicine, 12(6), 331-338.

Duff, M. C., \& Stuck, S. (2015). Paediatric concussion: Knowledge and practices of school speech-language pathologists. Brain Injury, 29(1), 6477.

Echlin, P. S., Tator, C, H., Cusimano, M.D., Cantu, R. C., Taunton, J. E., Upshur,
R. E., \& Skopelja, E. N. (2010). A prospective study of physicianobserved concussions during junior ice hockey: Implications for incidence rates. Neurosurgical Focus, 29(5), E4. Elkind, D. (1985). Egocentrism redux. Developmental Review, 5(3), 218-226. Esquivel, A., Haque, S., Keating, P., Marsh, S., \& Lemos, S. (2013). Concussion management, education, and returnto-play policies in high schools: A survey of athletic directors, athletic trainers, and coaches. Sports Health: $A$ Multidisciplinary Approach, 5(3), 258262.

Falavigna, A., Teles, A. R., Velho, M. C., Medeiros, G. S., Canabarro, C. T., de Braga, G. L.,...Kleber, F. D. (2012). Impact of an injury prevention program on teenagers' knowledge and attitudes: Results of the Pense Bem-Caxias do Sul Project. Journal of Neurosurgery: Pediatrics, 9(5), 562-568.

Gessel, L. M., Fields, S. K., Collins, C. L., Dick, R. W., \& Comstock, R. D. (2007). Concussions among United States high school and collegiate athletes. Journal of Athletic Training, 42(4), 495-503.

Glang, A. E., Koester, M. C., Chesnutt, J. C., Gioia, G. A., McAvoy, K., Marshall, S., \& Gau, J. M. (2015). The effectiveness of a web-based resource in improving postconcussion management in high schools. Journal of Adolescent Health, 56(1), 91-97. 
Gourley, M, M., Valovich McLeod, T. C., \& Bay, R. C. (2010). Awareness and recognition of concussion by youth athletes and their parents. Atbletic Training \& Sports Health Care, 2(5), 208-218.

Grimshaw, J. M., Shirran, L., Thomas, R., Mowatt, G., Fraser, C., Bero, L., ... \& O'Brien, M. A. (2001). Changing provider behavior: An overview of systematic reviews of interventions. Medical Care, 39(8) II2II45.

Guilmette, T. J., Malia, L. A., \& McQuiggan, M. D. (2007). Concussion understanding and management among New England high school football coaches. Brain Injury, 21(10), 1039-1047.

Halstead, M. E., \& Walter, K. D. (2010). Sport-related concussion in children and adolescents. Pediatrics, 126(3), 597-615.

Harmon, K. G., Drezner, J. A., Gammons M., Guskiewicz, K. M., Halstead, M., Herring, S. A.,... Roberts, W. O. (2013). American Medical Society for Sports Medicine position statement: Concussion in sport. British Journal of Sports Medicine, 47(1), 15-26.

Harvey, H. H. (2013). Reducing traumatic brain injuries in youth sports: Youth sports traumatic brain injury state laws, January 2009-December 2012. American Journal of Public Health, 103(7), 1249-1254.
Howe, P. D. (2004). Sport, professionalism, and pain: Ethnographies of injury and risk. London, UK: Routledge.

Jotwani, V., \& Harmon, K. G. (2010). Postconcussion syndrome in athletes. Current Sports Medicine Report, 9(1), 2126.

Karlin, A. M. (2011). Concussion in the pediatric and adolescent population: Different population, different concerns. Physical Medicine \& Rebabilitation, 3 (10 suppl 2), S369S379.

Kurowski, B. G, Pomerantz, W. J., Schaiper, C., \& Gittelman, M. A. (2014). Factors that influence concussion knowledge and self-reported attitudes in high school athletes. Journal of Trauma and Acute Care Surgery, 77(3 Suppl 1), S12-17.

Kurowski, B. G., Pomerantz, W. J., Schaiper, C., Ho, M., \& Gittelman, M. A. (2015). Impact of preseason concussion education on knowledge, attitudes, and behaviors of high school athletes. Journal of Trauma and Acute Care Surgery, 79(3), S21-28.

LaBond, V., Barber, K. R., \& Golden, I. J. (2014). Sports-related head injuries in students: Parents' knowledge, attitudes, and perceptions. NASN School Nurse, 29(4), 194-199.

Lin, A. C., Salzman, B. A., Bachman, S. L., Burke, R. V., Zaslow, T., Pisek, C. Z.,... Upperman, J. S. (2015). Assessment of parental knowledge and attitudes toward pediatric sports- 
related concussions. Sports Health: $A$ Multidisciplinary Approach, 7(2), 124129.

Lowrey, K. (2014). State laws addressing youth sports-related traumatic brain injury and the future of concussion law and policy. Journal of Business \& Technology Law, 10(1), 61-72.

Mannings, C., Kalynych, C., Joseph, M. M., Smotherman, C., \& Kraemer, D. F. (2014). Knowledge assessment of sports-related concussion among parents of children aged 5 years to 15 years enrolled in recreational tackle football. Journal of Trauma and Acute Care Surgery, 77(3 Suppl 1), S18-22. Marar, M., McIlvain, N. M., Fields, S. K., \& Comstock, R. D. (2012).

Epidemiology of concussions among United States high school athletes in 20 sports. American Journal of Sports Medicine, 40(4), 747-755.

McCrea, M., Hammeke, T., Olsen, G., Leo, P., \& Guskiewicz, K. (2004). Unreported concussion in high school football players: Implications for prevention. Clinical Journal of Sport Medicine, 14(1), 13-17.

McCrory, P., Davis, G., \& Makdissi, M. (2012). Second impact syndrome or cerebral swelling after sporting head injury. Current Sports Medicine Reports, 11(1), 21-23.

McCrory, P., Meeuwisse, W., Johnston, K., Dvorak, J., Aubry, M., Molloy, M., \& Cantu, R. (2017). Consensus statement on concussion in sport:
The 5th International Conference on Concussion in Sport held in Berlin, October 2016. British Journal of Sports Medicine, 5(11), 838-847.

Meehan, W. P., \& Bachur, R. G. (2009). Sport-related concussion. Pediatrics, 123(1), 114-123.

Miyashita, T. L., Timpson, W. M., Frye, M. A., \& Gloeckner, G. W. (2013). The impact of an educational intervention on college athletes' knowledge of concussions. Clinical Journal of Sport Medicine, 23(5), 349-353.

Moser, R. S., Glatts, C., \& Schatz, P. (2012). Efficacy of immediate and delayed cognitive and physical rest for treatment of sports-related concussion. The Journal of Pediatrics, 161(5), 922-926.

Mrazik, M., Bawani, F., \& Krol, A. L. (2011). Sports-related concussions: Knowledge translation among minor hockey coaches. Clinical Journal of Sport Medicine, 21(4), 315-319.

Mrazik, M., Perra, A., Brooks, B. L., \& Naidu, D. (2015). Exploring minor hockey players' knowledge and attitudes toward concussion: Implications for prevention. Journal of Head Trauma Rehabilitation, 30(3), 219227.

Naftel, K. G., Yust, E. M., Nichols, M. H., King, W. D., \& Davis, D. (2014). Knowledge and management of sports concussions among coaches and certified athletic trainers in 
Alabama. Southern Medical Journal, 107(7), 418-423.

National Federation of State High School Associations (NFHS). (2017). Concussion in Sports. Retrieved from: https://nfhslearn.com/courses/6106 4/concussion-in-sports

National Research Council \& Committee on Sports-Related Concussions in Youth. (2014). Sports-related concussions in youth: improving the science, changing the culture. Bethesda, MD: National Academies Press.

O'Donoghue, E. M., Onate, J. A., Van Lunen B., \& Peterson, C. L. (2009). Assessment of high school coaches' knowledge of sport-related concussions. Athletic Training Sports Health Care, 1(3), 120-132.

Oregon Center for Applied Science (ORCAS). (2011). School-wide Concussion Management. Retrieved from: http://brain101.orcasinc.com/ Paradis, L. (2014, September 1). Parks and recreation's role in the concussion campaign. Parks \& Recreation.

Retrieved from http://www.parksandrecreation.org/ 2014/September/Parks-and-

Recreation-Role-in-the-ConcussionCampaign/

Provvidenza, C., Engebretsen, L., Tator, C., Kissick, J., McCrory, P., Sills, A., \& Johnston, K. M. (2013). From consensus to action: Knowledge transfer, education and influencing policy on sports concussion. British
Journal of Sports Medicine, 47(5), 332338.

Provvidenza, C. F., \& Johnston, K. M. (2009). Knowledge transfer principles as applied to sport concussion education. British Journal of Sports Medicine, 43(Suppl 1), i68-i75.

Register-Mihalik, J. K., Linnan, L. A., Marshall, S.W., Valovich McLeod, T. C., Mueller, F. O., \& Guskiewicz, K. M. (2013). Using theory to understand high school aged athletes' intentions to report sport-related concussion: Implications for concussion education initiatives. Brain Injury, 27(7-8), 878-886.

Rosenbaum, A. M., \& Arnett, P. A. (2010). The development of a survey to examine knowledge about and attitudes toward concussion in highschool students. Journal of Clinical and Experimental Neuropsychology, 32(1), 4455.

Sarmiento, K., Mitchko, J., Klein, C., \& Wong, S. (2010). Evaluation of the Centers for Disease Control and Prevention's concussion initiative for high school coaches: "Heads Up: Concussion in High School Sports." Journal of School Health, 80(3), 112-118.

Sefton, J. M., Pirog, K., Capitao, A., Harackiewicz, D., \& Cordova, M. L. (2004). An examination of factors that influence knowledge and reporting of mild brain injuries in 
collegiate football. Journal of Athletic

Training, 39, S52-S53.

Shenouda, C., Hendrickson, P., Davenport, K., Barber, J., \& Bell, K. R. (2012).

The effects of concussion legislation one year later-what have we learned: A descriptive pilot survey of youth soccer player associates. Physical Medicine \& Rehabilitation, 4(6), 427435.

Shroyer, J., \& Stewart, C. (2016).

Knowledge of concussions by high school coaches in a rural environment. Physical Educator, 73(2), 373-388.

Straus, S. E., Tetroe, J, \& Graham, I. D. (2013). Knowledge translation in health care: Moving from evidence to practice. West Sussex, UK: Wiley \& Sons. Sullivan, S. J., Schneiders, A. G., Cheang, C. W., Kitto, E., Lee, H., Redhead, J., ... \& McCrory, P. R. (2012). 'What's happening?' A content analysis of concussion-related traffic on Twitter. British Journal of Sports Medicine, 46(4), 258-263.

Sussingham, R. (2015, August). Florida first state to require concussion training for high school athletes. State-Impact. Retrieved from https://stateimpact.npr.org/florida/ 2015/08/31/florida-first-state-torequire-concussion-training-for-highschool-athletes/

Valovich McLeod, T. C., Schwartz, C., \& Bay, R. C. (2007). Sport-related concussion misunderstandings among youth coaches. Clinical Journal of Sport Medicine, 17(2), 140-142.

Weber, M. L., Welch, C. E., Parsons, J. T., \& Valovich McLeod, T. C. (2015). School nurses' familiarity and perceptions of academic accommodations for student-athletes following sport-related concussion. Journal of School Nursing, 31(2), 146154.

Williams, D., Sullivan, S. J., Schneiders, A. G., Ahmed, O. H., Lee, H., Balasundaram, A. P., \& McCrory, P. R. (2014). Big hits on the small screen: An evaluation of concussionrelated videos on YouTube. British Journal of Sports Medicine, 48(2), 107111.

Yorke, A, M., Littleton, S., \& Alsalaheen, B. A. (2016). Concussion attitudes and beliefs, knowledge, and clinical practice: Survey of physical therapists. Physical Therapy, 96(7), 1018-1028.

Young, K., \& White, P. (1995). Sport, physical danger, and injury: The experiences of elite women athletes. Journal of Sport \& Social Issues, 19(1), 45-61.

Zemek, R., Eady, K., Moreau, K., Farion, K. J., Solomon, B., Weiser, M., \& Dematteo, C. (2014). Knowledge of paediatric concussion among frontline primary care providers. Paediatrics and Child Health, 19(9), 475-480.

Zemek, R., Eady, K., Moreau, K., Farion, K. J., Solomon, B., Weiser, M., \& 
Dematteo, C. (2015). Canadian

pediatric emergency physician

knowledge of concussion diagnosis

and initial management. Canadian

Journal of Emergency Medicine, 17(2),

115-122. 


\section{Figure}

Figure 1

Flow Chart of Review Process
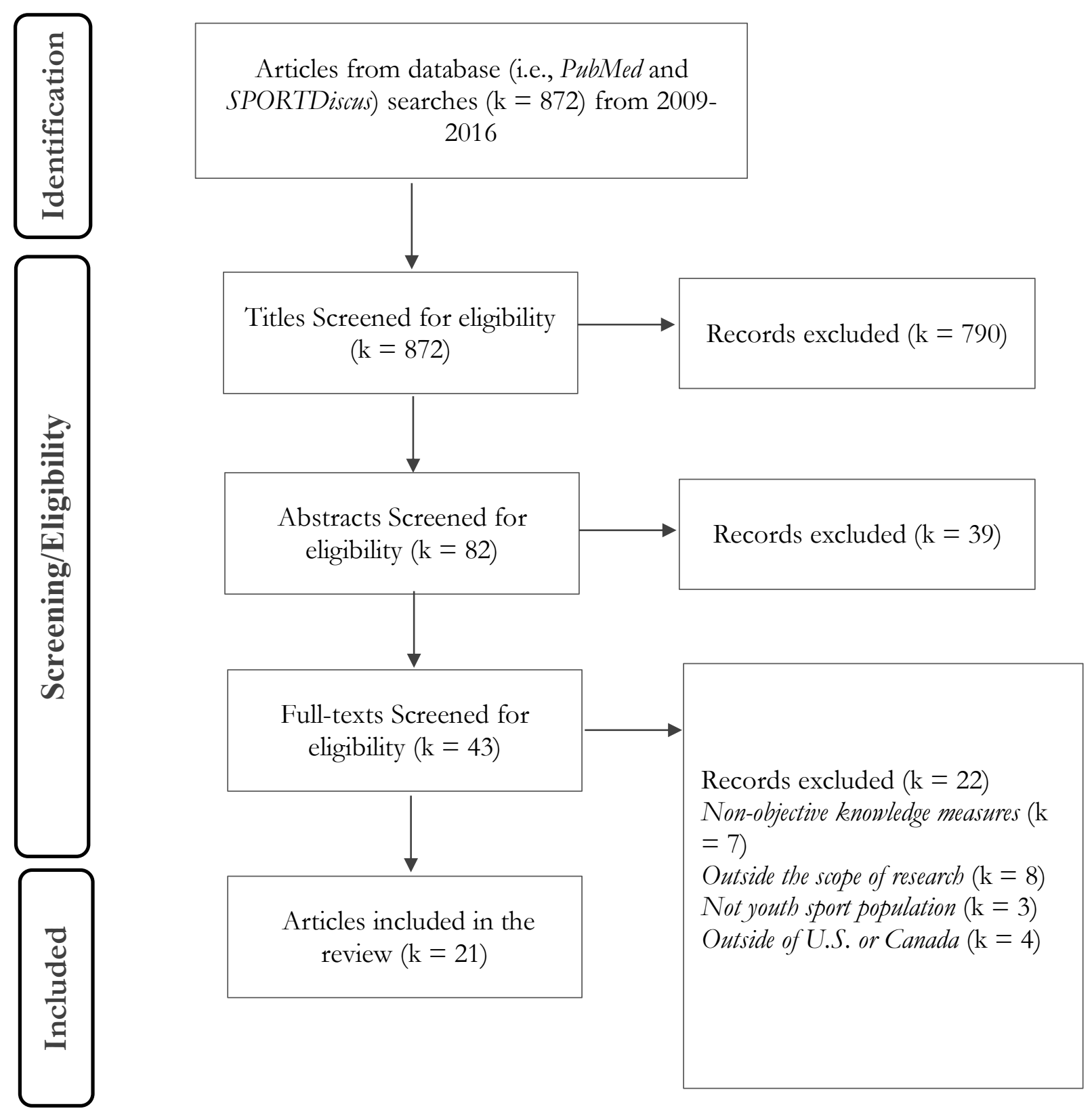
Table 1

Chronological published reports of youth sport stakeholders' concussion knowledge

\begin{tabular}{|c|c|c|c|c|c|c|}
\hline Date & Reference & Stakeholder(s) & Sport(s) & Level & Key knowledge measure(s) & Summary of the knowledge assessed \\
\hline 2016 & $\begin{array}{l}\text { Anderson } \\
\text { et al. }\end{array}$ & $\begin{array}{l}\text { Athletes } \\
(\mathrm{n}=120)\end{array}$ & Football & $\begin{array}{l}\text { Interscholastic } \\
\text { sports }\end{array}$ & $\begin{array}{l}\text { (1) Signs/symptoms } \\
\text { (2) Medical complications }\end{array}$ & $\begin{array}{l}\text { More than } 75 \% \text { of respondents correctly identified five } \\
\text { out of the six listed symptoms related to concussions. } \\
\text { Approximately } 92 \% \text { of respondents agreed that } \\
\text { improper management of concussions could lead to } \\
\text { severe health consequences. }\end{array}$ \\
\hline 2016 & $\begin{array}{l}\text { Shroyer } \\
\text { et al. }\end{array}$ & $\begin{array}{l}\text { Coaches } \\
(\mathrm{n}=53)\end{array}$ & Multiple & $\begin{array}{l}\text { Interscholastic } \\
\text { sports }\end{array}$ & $\begin{array}{l}\text { (1) Concussion facts } \\
\text { (2) RTP guidelines }\end{array}$ & $\begin{array}{l}\text { Nearly half of respondents did not know that high } \\
\text { school athletes typically take longer to recover from } \\
\text { concussions than older athletes. Most of respondents } \\
\text { were familiar with RTP guidelines. }\end{array}$ \\
\hline 2015 & $\begin{array}{l}\text { Kurowski } \\
\text { et al. }\end{array}$ & $\begin{array}{l}\text { aAthletes } \\
(\mathrm{n}=262)\end{array}$ & $\begin{array}{l}\text { Football, } \\
\text { Soccer, } \\
\text { Basketball, \& } \\
\text { Wrestling }\end{array}$ & $\begin{array}{l}\text { Interscholastic } \\
\text { sports }\end{array}$ & $\begin{array}{l}\text { (1) Concussion facts } \\
\text { (2) Signs/symptoms } \\
\text { (3) RTP guidelines } \\
\text { (4) Medical complications }\end{array}$ & $\begin{array}{l}\text { Overall, athletes exhibited a moderate understanding } \\
\text { of concussion signs and symptoms. However, athletes } \\
\text { reported a low to moderate understanding of the less } \\
\text { distinct signs/symptoms such as emotional changes, } \\
\text { neck pain, hallucinations and vomiting. Over } 92 \% \text { of } \\
\text { athletes agreed that they must complete a gradual } \\
\text { return to play before returning fully to sports. Most } \\
(86 \%) \text { agreed that, if a second concussion occurs } \\
\text { before the first one is healed, there is a risk of death. } \\
\text { Approximately } 61 \% \text { believed that concussions can be } \\
\text { only sustained if hit in the head. }\end{array}$ \\
\hline 2015 & $\begin{array}{l}\text { Lin } \\
\text { et al. }\end{array}$ & $\begin{array}{l}\text { Parents } \\
(\mathrm{n}=214)\end{array}$ & $\mathrm{N} / \mathrm{A}$ & $\begin{array}{l}\text { Interscholastic } \\
\text { sports }\end{array}$ & $\begin{array}{l}\text { (1) Signs / symptoms } \\
\text { (2) RTP guidelines }\end{array}$ & $\begin{array}{l}\text { Respondents scored an average of } 18.4 \text { (possible, } 0-25 \text { ) } \\
\text { on the Concussion Knowledge Index. }\end{array}$ \\
\hline 2015 & $\begin{array}{l}\text { Mrazik } \\
\text { et al. }\end{array}$ & $\begin{array}{l}\text { bAthletes } \\
(\mathrm{n}=183)\end{array}$ & Hockey & $\begin{array}{l}\text { Recreational } \\
\text { sports }\end{array}$ & $\begin{array}{l}\text { (1) Concussion facts } \\
\text { (2) RTP guidelines }\end{array}$ & $\begin{array}{l}\text { Most }(86.8 \%) \text { hockey players were familiar with the } \\
\text { causes of concussions. However, one-half of } \\
\text { respondents were not familiar with the prevalence of } \\
\text { concussions. Approximately } 68 \% \text { of hockey players } \\
\text { indicated that they were unfamiliar with RTP } \\
\text { protocols. }\end{array}$ \\
\hline
\end{tabular}

RTP = Return-to-Play 
Table 1 Continued

\begin{tabular}{|c|c|c|c|c|c|c|}
\hline Date & Reference & Stakeholder(s) & Sport(s) & Level & Key knowledge measure(s) & Summary of the knowledge assessed \\
\hline 2014 & $\begin{array}{l}\text { Chrisman } \\
\text { et al. }\end{array}$ & $\begin{array}{l}\text { Coaches } \\
(\mathrm{n}=270)\end{array}$ & $\begin{array}{l}\text { Football \& } \\
\text { Soccer }\end{array}$ & $\begin{array}{l}\text { Interscholastic } \\
\text { sports }\end{array}$ & $\begin{array}{l}\text { (1) Concussion facts } \\
\text { (2) Signs/symptoms } \\
\text { (3) RTP guidelines }\end{array}$ & $\begin{array}{l}\text { The majority }(95 \%) \text { of respondents knew that concussions } \\
\text { can be caused without a direct blow to the head. Also, most } \\
\text { respondents were knowledgeable about common } \\
\text { signs/symptoms of a concussion, but did not correctly } \\
\text { identify many of the mental symptoms (i.e., being more } \\
\text { emotional, anxious and sad). More than } 95 \% \text { of respondents } \\
\text { would not allow an athlete to return to play even if } \\
\text { symptoms appeared only briefly ( }<15 \text { min). Only } 55.2 \% \\
\text { were familiar with the term "graduated return to play." }\end{array}$ \\
\hline 2014 & $\begin{array}{l}\text { Cournoyer } \\
\text { et al. }\end{array}$ & $\begin{array}{l}\text { Athletes } \\
(\mathrm{n}=314)\end{array}$ & Football & $\begin{array}{l}\text { Interscholastic } \\
\text { sports }\end{array}$ & $\begin{array}{l}\text { (1) Signs/symptoms } \\
\text { (2) Medical complications }\end{array}$ & $\begin{array}{l}\text { Although most respondents correctly identified the common } \\
\text { signs/symptoms of a concussion such as headache, dizziness } \\
\text { and confusion, many failed to recognize the less apparent } \\
\text { signs/symptoms (e.g., nausea, vomiting, personality change, } \\
\text { trouble falling asleep, being more emotional and anxious). } \\
\text { While } 93 \% \text { of respondents correctly identified persistent } \\
\text { headache as a consequence of improperly managing } \\
\text { concussions, only } 60-70 \% \text { knew that brain hemorrhage, } \\
\text { coma and death could be possible consequences as well. }\end{array}$ \\
\hline 2014 & $\begin{array}{l}\text { Kurowski } \\
\text { et al. }\end{array}$ & $\begin{array}{l}\text { Athletes } \\
(\mathrm{n}=496)\end{array}$ & $\begin{array}{l}\text { Football, } \\
\text { Soccer, } \\
\text { Basketball, \& } \\
\text { Wrestling }\end{array}$ & $\begin{array}{l}\text { Interscholastic } \\
\text { sports }\end{array}$ & $\begin{array}{l}\text { (1) Concussion facts } \\
\text { (2) Signs/symptoms }\end{array}$ & $\begin{array}{l}\text { Respondents correctly identified } 68.8 \% \text { of the knowledge- } \\
\text { based questions on concussion facts. Less than half failed to } \\
\text { realize that emotional changes and neck pain could result } \\
\text { from concussions. Approximately, } 41.7 \% \text { did not know that } \\
\text { a person can get a concussion other than receiving hit in the } \\
\text { head, and } 67 \% \text { knew that a person with previous } \\
\text { concussion(s) is more likely to get another. }\end{array}$ \\
\hline 2014 & $\begin{array}{l}\text { LaBond et } \\
\text { al. }\end{array}$ & $\begin{array}{l}\text { Parents } \\
(\mathrm{n}=235)\end{array}$ & Multiple & $\begin{array}{l}\text { Interscholastic } \\
\text { sports }\end{array}$ & $\begin{array}{l}\text { (1) Concussion facts } \\
\text { (2) RTP guidelines } \\
\text { (3) Medical complications }\end{array}$ & $\begin{array}{l}\text { More than half of respondents did not know that } \\
\text { concussion severity was typically higher among children. } \\
\text { Sixty-one percent of respondents revealed that they had } \\
\text { limited knowledge regarding RTP guidelines although } 99 \% \\
\text { agreed that a concussed athlete should be evaluated by a } \\
\text { physician before returning to play. Approximately } 35 \% \text { did } \\
\text { not know that repeated head trauma could lead to dementia. }\end{array}$ \\
\hline
\end{tabular}

b Control group (non-player)
RTP = Return-to-Play

not know that repeated head trauma could lead to dementia. 
Table 1 Continued

\begin{tabular}{|c|c|c|c|c|c|c|}
\hline Date & Reference & Stakeholder(s) & Sport(s) & Level & Key knowledge measure(s) & Summary of the knowledge assessed \\
\hline 2014 & $\begin{array}{l}\text { Mannings et } \\
\text { al. }\end{array}$ & $\begin{array}{l}\text { Parents } \\
(\mathrm{n}=130)\end{array}$ & Football & $\begin{array}{l}\text { Recreational } \\
\text { sport }\end{array}$ & $\begin{array}{l}\text { (1) Concussion facts } \\
\text { (2) Signs/symptoms }\end{array}$ & $\begin{array}{l}\text { Approximately two-thirds of respondents failed to realize } \\
\text { that a concussion is a mild traumatic brain injury. Moreover, } \\
42 \% \text { were unaware that a concussion could be caused by } \\
\text { something other than a direct blow to the head. Many } \\
\text { respondents were unable to identify irritability, emotional } \\
\text { outburst and sleeping difficulty as possible symptoms of a } \\
\text { concussion. }\end{array}$ \\
\hline 2014 & Naftel et al. & $\begin{array}{l}\text { Coaches } \\
(\mathrm{n}=402)\end{array}$ & Multiple & $\begin{array}{l}\text { Interscholastic } \\
\text { sports }\end{array}$ & $\begin{array}{l}\text { (1) Concussion facts } \\
\text { (2) Signs/symptoms }\end{array}$ & $\begin{array}{l}\text { Although } 85.7 \% \text { of coaches correctly identified the } \\
\text { concussion signs/symptoms, they had difficulty recognizing } \\
\text { the more subtle and profound symptoms such as sleep } \\
\text { troubles and personality changes. }\end{array}$ \\
\hline 2013 & $\begin{array}{l}\text { Bloodgood et } \\
\text { al. }\end{array}$ & $\begin{array}{l}\text { Athletes } \\
(\mathrm{n}=252) \& \\
\text { Parents } \\
(\mathrm{n}=300)\end{array}$ & $\mathrm{N} / \mathrm{A}$ & $\begin{array}{l}\text { Recreational } \\
\text { sports }\end{array}$ & $\begin{array}{l}\text { (1) Concussion facts } \\
\text { (2) Signs/symptoms }\end{array}$ & $\begin{array}{l}\text { Among respondents that had heard about concussions, only } \\
\text { about one-quarter indicated that they were familiar with the } \\
\text { definition of a concussion and one or more of its } \\
\text { signs/symptoms. }\end{array}$ \\
\hline 2013 & $\begin{array}{l}\text { Esquivel et } \\
\text { al. }\end{array}$ & $\begin{array}{l}\text { Coaches } \\
(\mathrm{n}=119)\end{array}$ & $\begin{array}{l}\text { Football, } \\
\text { Hockey, } \\
\text { \& Soccer }\end{array}$ & $\begin{array}{l}\text { Interscholastic } \\
\text { sports }\end{array}$ & $\begin{array}{l}\text { (1) Signs/symptoms } \\
\text { (2) RTP guidelines }\end{array}$ & $\begin{array}{l}\text { Most respondents were able to identify common } \\
\text { signs/symptoms associated with a concussion. All } \\
\text { respondents agreed that a concussed athlete should not } \\
\text { return to play the same day of the injury. More than } 90 \% \\
\text { required physician care and clearance before returning to } \\
\text { play. }\end{array}$ \\
\hline 2013 & $\begin{array}{l}\text { Register- } \\
\text { Mihalik et al. }\end{array}$ & $\begin{array}{l}\text { Athletes } \\
(\mathrm{n}=167)\end{array}$ & $\begin{array}{l}\text { Football, } \\
\text { Soccer, } \\
\text { Lacrosse, } \\
\& \\
\text { Cheerlead } \\
\text { - ing }\end{array}$ & $\begin{array}{l}\text { Interscholastic } \\
\text { sports }\end{array}$ & $\begin{array}{l}\text { (1) Concussion facts } \\
\text { (2) Signs/symptoms } \\
\text { (3) Medical complications }\end{array}$ & $\begin{array}{l}\text { Most }(84.7 \%) \text { athletes were aware that a concussion can } \\
\text { occur without losing consciousness, and } 88.5 \% \text { correctly } \\
\text { identified that a concussion is an injury to the brain. While } \\
\text { most respondents correctly identified the common } \\
\text { signs/symptoms of a concussion, many did not realize that } \\
\text { nausea and amnesia could also be indicative of a concussion. } \\
\text { The majority were familiar with the potential complications } \\
\text { from suffering recurrent concussions and/or prematurely } \\
\text { returning to play. }\end{array}$ \\
\hline 2012 & Bramley et al. & $\begin{array}{l}\text { Coaches } \\
(\mathrm{n}=314)\end{array}$ & Hockey & $\begin{array}{l}\text { Recreational } \\
\text { sports }\end{array}$ & (1) RTP guidelines & $\begin{array}{l}\text { Using clinical vignettes, } 80 \% \text { or more of respondents } \\
\text { indicated that they would not allow a concussed athlete to } \\
\text { return to a game; however, a small percentage would allow } \\
\text { an athlete to return depending on the severity of a } \\
\text { concussion. Respondents noted that they were more likely to } \\
\text { allow return to play for championship games as opposed to } \\
\text { regular games. }\end{array}$ \\
\hline
\end{tabular}

RTP = Return-to-Play 
Table 1 Continued

\begin{tabular}{|c|c|c|c|c|c|c|}
\hline Date & Reference & Stakeholder(s) & Sport(s) & Level & Key knowledge measure(s) & Summary of the knowledge assessed \\
\hline 2012 & $\begin{array}{l}\text { Shenouda et } \\
\text { al. }\end{array}$ & $\begin{array}{l}\text { Parents } \\
(\mathrm{n}=246), \\
\text { Coaches } \\
(\mathrm{n}=78)\end{array}$ & Soccer & $\begin{array}{l}\text { Recreational } \\
\text { sports }\end{array}$ & $\begin{array}{l}\text { (1) Concussion facts } \\
\text { (2) Signs/symptoms } \\
\text { (3) RTP guidelines } \\
\text { (4) Medical complications }\end{array}$ & $\begin{array}{l}\text { Most respondents displayed high proficiency in concussion } \\
\text { facts (i.e., definition, causes, treatment) and correctly } \\
\text { identified most of the symptoms associated with a } \\
\text { concussion. Although } 73 \% \text { of respondents understood that } \\
\text { written clearance was required from a trained professional } \\
\text { for returning to play, many did not know that a trained } \\
\text { professional could be a volunteer. Eighty-three percent of } \\
\text { respondents knew that continuing to play with a concussion } \\
\text { can lead to further injury and/or death. }\end{array}$ \\
\hline 2011 & Mrazik et al. & $\begin{array}{l}\text { Coaches } \\
(\mathrm{n}=178)\end{array}$ & Hockey & $\begin{array}{l}\text { Recreational } \\
\text { sports }\end{array}$ & $\begin{array}{l}\text { (1) Concussion facts } \\
\text { (2) Signs/symptoms } \\
\text { (3) RTP guidelines }\end{array}$ & $\begin{array}{l}\text { Most }(84 \%) \text { agreed that concussions can be sustained } \\
\text { without a blow to the head and that a loss of consciousness } \\
\text { is not required for sustaining concussions. More than } 90 \% \\
\text { reported that they would not allow players to return to play } \\
\text { if a concussion is suspected with symptoms of headache, } \\
\text { loss of consciousness and forgetfulness. However, about } \\
12 \% \text { would allow players to return to play if concussion } \\
\text { symptoms had improved by the end of the game. }\end{array}$ \\
\hline 2010 & $\begin{array}{l}\text { Gourley } \\
\text { et al. }\end{array}$ & $\begin{array}{l}\text { Athletes } \\
(\mathrm{n}=73) \& \\
\text { Parents } \\
(\mathrm{n}=100)\end{array}$ & Multiple & $\begin{array}{l}\text { Recreational } \\
\text { sports }\end{array}$ & $\begin{array}{l}\text { (1) Concussion facts } \\
\text { (2) Signs/symptoms } \\
\text { (3) RTP guidelines }\end{array}$ & $\begin{array}{l}\text { Approximately } 77 \% \text { of athletes and } 85 \% \text { of parents agreed } \\
\text { that a concussion only occurs when an athlete blacks out. } \\
\text { Both parents and athletes correctly identified approximately } \\
9 \text { out of } 16 \text { signs } / \text { symptoms questions. On the scenario } \\
\text { question, } 66 \% \text { percent of athletes and } 68 \% \text { of parents agreed } \\
\text { that an athlete who only experiences mild dizziness and } \\
\text { headache following a blow to the head should not return to } \\
\text { play that day. Additionally, only } 62 \% \text { of athletes and } 56 \% \text { of } \\
\text { parents agreed that a youth athlete should return to play in a } \\
\text { slow progressive manner. }\end{array}$ \\
\hline 2009 & $\begin{array}{l}\text { O'Donoghue } \\
\text { et al. }\end{array}$ & $\begin{array}{l}\text { Coaches } \\
(\mathrm{n}=126)\end{array}$ & Multiple & $\begin{array}{l}\text { Interscholastic } \\
\text { sports }\end{array}$ & $\begin{array}{l}\text { (1) Concussion facts } \\
\text { (2) Signs/symptoms } \\
\text { (3) RTP guidelines }\end{array}$ & $\begin{array}{l}\text { Approximately } 43 \% \text { of respondents indicated that an athlete, } \\
\text { regardless of age, recovers from concussion at the same rate. } \\
\text { Respondents scored an average of } 92 \% \text { on the recognition } \\
\text { (i.e., signs/symptoms) section of the survey. However, they } \\
\text { scored only } 79 \% \text { on the management section (i.e., RTP } \\
\text { guidelines). }\end{array}$ \\
\hline
\end{tabular}

RTP = Return-to-Play 
Table 1 Continued

\begin{tabular}{|c|c|c|c|c|c|c|}
\hline Date & Reference & Stakeholder(s) & Sport(s) & Level & Key knowledge measure(s) & Summary of the knowledge assessed \\
\hline 2009 & Cusimano & $\begin{array}{l}\text { Athletes } \\
(\mathrm{n}=267), \\
\text { Parents } \\
(\mathrm{n}=92), \\
\text { Coaches } \\
(\mathrm{n}=22)\end{array}$ & Hockey & $\begin{array}{l}\text { Recreational } \\
\text { sports }\end{array}$ & $\begin{array}{l}\text { (1) Concussion facts } \\
\text { (2) Signs/symptoms } \\
\text { (3) RTP guidelines }\end{array}$ & $\begin{array}{l}\text { Forty-five percent of athletes did not correctly identify the } \\
\text { causes of concussions. Approximately one-quarter of the } \\
\text { parents and coaches, and a quarter to a half of athletes } \\
\text { were not aware of any concussion symptoms or were able } \\
\text { to name only one symptom. About a quarter of athletes } \\
\text { did not know or thought it was acceptable to continue } \\
\text { playing while having concussive signs/symptoms. } \\
\text { Additionally, 33- } 40 \% \text { of athletes believed that they can } \\
\text { return to play prematurely as long as they are feeling } \\
\text { better. }\end{array}$ \\
\hline 2009 & Coghlin et al. & Parents $(n=114)$ & Hockey & $\begin{array}{l}\text { Recreational } \\
\text { sports }\end{array}$ & $\begin{array}{l}\text { (1) Concussion facts } \\
\text { (2) Signs/symptoms } \\
\text { (3) RTP guidelines }\end{array}$ & $\begin{array}{l}\text { Approximately } 86 \% \text { of respondents knew that concussions } \\
\text { can be caused by a blow to the neck, jaw or elsewhere in } \\
\text { the body. While respondents had decent understanding of } \\
\text { common signs/symptoms of a concussion (e.g., nausea, } \\
\text { fatigue, slurred speech, etc.), they did not know that } \\
\text { difficulty with sleep, disorientation and emotional } \\
\text { irritability were also key components of recognizing a } \\
\text { concussion. Over } 95 \% \text { indicated that a concussed athlete } \\
\text { should not return to play the same day of the injury. }\end{array}$ \\
\hline
\end{tabular}

RTP = Return-to-Play 